\title{
The influence of the serotonergic system on the personality and quality of life of postmenopausal women
}

This article was published in the following Dove Press journal:

Clinical Interventions in Aging

13 June 2017

Number of times this article has been viewed

\section{Daria Schneider-Matyka' \\ Anna Jurczak' \\ Małgorzata Szkup' \\ Agnieszka Samochowiec ${ }^{2}$ \\ Anna Grzywacz ${ }^{3}$ \\ Sylwia Wieder-Huszla' \\ Elżbieta Grochans'}

'Department of Nursing, Pomeranian Medical University in Szczecin,

${ }^{2}$ Department of Clinical Psychology, Institute of Psychology, University of Szczecin, ${ }^{3}$ Department of Psychiatry, Pomeranian Medical University in Szczecin, Szczecin, Poland
Correspondence: Elżbieta Grochans

Department of Nursing,

Pomeranian Medical University

in Szczecin, 48 Żołnierska Street,

7I-2I 0 Szczecin, Poland

$\mathrm{Tel}+48914800910$

Fax +48 9l 4800905

Email grochans@pum.edu.pl
Abstract: The aim of this study was to establish the relationship between personality traits of postmenopausal women and the presence of the 44-bp VNTR polymorphism in the serotonin transporter (5-HTT) (SLC6A4) promoter region and the 30-bp VNTR polymorphism in the $M A O-A$ promoter region. The study's aim was also to determine the influence of personality traits on the quality of postmenopausal women's lives. The study involved 214 postmenopausal women from northwest Poland, with an average age of $56.8 \pm 4.08$ years. It was performed using the Temperament and Character Inventory-Revised and the Short Form Health Survey. DNA polymorphisms were identified by means of polymerase chain reaction. Analysis demonstrated that the s/s genotype was significantly more common than the $1 / 1$ genotype in women with higher fear of uncertainty. In a group with higher enlightened second nature and empathy, the $1 /$ s genotype was considerably more common than the $1 / 1$ genotype. There were statistically significant associations between selected aspects of quality of life and personality traits such as enlightened second nature, transpersonal identification, purposefulness, and self-transcendence. The s/s genotype of the 44-bp VNTR polymorphism in the 5-HTT (SLC6A4) promoter region may increase the tendency to avoid harm within the fear of uncertainty dimension. Carriers of this genotype may have predisposition to anxiety and depressive disorders. The $1 / \mathrm{s}$ genotype of the 44-bp VNTR polymorphism in the 5-HTT (SLC6A4) promoter region contributes to increased expression of enlightened second nature and empathy. Some personality traits may influence the quality of women's lives.

Keywords: menopause, quality of life, personality, 5-HTT, MAO-A

\section{Introduction}

The development of molecular biology and behavioral genetics has contributed to the initiation of research on genetic variants responsible for expression of personality traits. Cloninger proposed that personality variation is underlain by biogenetically distinct and moderately heritable dimensions. Since he assumed that these dimensions are related to specific types of neurotransmitter systems, the research focused on the polymorphisms of genes encoding neurotransmitter transporters. ${ }^{1}$ Cloninger identified three dimensions of personality, or so-called temperaments, that influence the behavior patterns of individual response to environmental stimuli. He linked them with the activity of neurotransmitter systems as follows: novelty seeking (NS) with the dopaminergic system, harm avoidance (HA) with the serotonergic system, and reward dependence (RD) with the noradrenergic system. NS defined as a tendency to react actively to new stimuli consists of four subscales, namely exploratory excitability (NS1), impulsiveness (NS2), extravagance (NS3), and disorderliness (NS4). 
HA referring to a tendency to avoid any activity in response to negative stimuli also includes four subscales: anticipatory worry (HA1), fear of uncertainty (HA2), shyness (HA3), and fatigability (HA4). RD that denotes one's predisposition to react to positive stimuli comprises of three subscales: sentimentality (RD1), attachment (RD3), and dependence (RD4). Based on this assumption, Cloninger developed the Tridimensional Personality Questionnaire. Then, to the three aforementioned temperaments, he added persistence $(\mathrm{P})$, defined as the ability to generate and maintain arousal and motivation internally in the absence of immediate external reward, and three so-called characters: self-directedness (SD) that denotes the ability of a person to control, regulate, and adjust his/her behavior to a situation and consists of five subscales, which are responsibility (SD1), purposefulness (SD2), resourcefulness (SD3), self-acceptance (SD4), and enlightened second nature (SD5); cooperativeness (C) that denotes the ability to identify and accept behaviors of other people and comprises five subscales, which are social acceptance (C1), empathy (C2), helpfulness (C3), compassion (C4), and pure-hearted conscience (C5), and self-transcendence (ST) defined as a personality trait associated with experiencing spiritual ideas such as considering oneself an integral part of the universe and includes three subscales, which are selfforgetfulness (ST1), transpersonal identification (ST2), and spiritual acceptance (ST3). Thus, Cloninger created a newer version of the questionnaire, namely the Temperament and Character Inventory (TCI). ${ }^{1-3}$ According to Cloninger, temperament is only slightly related to experience. It represents automatic responses in information processing and learning, which are presumed to be heritable. Individual differences in temperament are conditioned by, among others, differences in the functioning of neurotransmitter systems. Character, on the other hand, reflects personality development in the context of learning and environmental experiences. Character depends on the connections within the hippocampus and neocortex. ${ }^{1,2}$

Research conducted so far provides evidence for the influence of the serotonin transporter (5-HTT) gene (SLC6A4) on developing anxiety-related personality traits. Polymorphisms in this gene are characterized by the insertion or deletion of a 44-bp fragment, which results in the creation of a long (1) allele consisting of $528 \mathrm{bp}$ and a short (s) allele that is 44-bp shorter than the "l" allele. The "s" allele of the 5-HTT gene presumably causes the lower expression and weaker function of serotonin transporter, resulting in disturbance of transmission and consequently higher impulsiveness and avoidant personality. ${ }^{1,4}$ In carriers of the s-allele genotype of the 5-HTT gene (SLC6A4), stressful life events may evoke more severe depressive symptoms and trigger more frequent suicidal attempts than in individuals with the "l" allele. 5 According to Cloninger, HA predisposes to the occurrence of depressive symptoms and/or anxiety disorders. ${ }^{1} \mathrm{HA}$ is a personality trait characterized by excessive anxiety, pessimism, and shyness accompanied by constant fear, uncertainty, and tiring out quickly. HA is supposed to be linked with high serotonergic activity. ${ }^{6,7} \mathrm{MAO}$ is an enzyme responsible for deamination of serotonin. Low MAO-A activity may lead to psychiatric disorders. The most widely analyzed polymorphism so far is a functional VNTR polymorphism in the promoter region. It consists of 2-5 repetitions of the 30-bp fragment. Studies show that depression in women is related to the presence of alleles causing higher MAO-A activity. ${ }^{8}$ Low activity of MAO-A is associated with high activity of serotonin, which is catalyzed by MAO-A to 5-hydroxyindoleacetic acid in the raphe nuclei. ${ }^{2}$

Quality of life (QoL) is a multidimensional concept covering physical, mental, emotional, and social functioning domains, associated with health and disease. ${ }^{9}$ The most recent studies show that older people, including postmenopausal women, are more satisfied with their lives, and that they experience weaker stress, anxiety, and anger than middle-aged people despite worsening health status and lower efficiency. ${ }^{10}$ In the postmenopausal period, women face symptoms that can be divided into short-term symptoms, such as menstrual vasomotor disturbances ${ }^{11}$ and dysfunction of the urogenital tract, ${ }^{12,13}$ and long-term symptoms, including cardiovascular and metabolic diseases, ${ }^{14}$ postmenopausal osteoporosis, ${ }^{15}$ as well as breast and endometrial cancers. They also experience a number of psychological symptoms, such as sudden mood changes, difficulties in coping with stress of daily living, depressive states, getting tired quickly, nervousness, irritation, poor concentration, deterioration of memory, somatic disorders that do not respond to treatment, and full-blown depression. The direct impact of vasomotor symptoms, hormone replacement therapy, and adverse life events on this risk was not confirmed. Nevertheless, physical symptoms and frequent mood changes during menopause can contribute to the course of depression. ${ }^{16}$

Depression and depressive symptoms affect mainly women, and the perimenopausal period favors their occurrence due to biological and non-biological etiological factors. ${ }^{17-19}$ Improvement in women's QoL in this period of life should be a key purpose of therapy and hence the necessity for interdisciplinary care for women in this period of life..$^{20,21}$ 


\section{Aim of the study}

The aim of this study was to determine the relationship between personality traits of postmenopausal women according to the Temperament and Character Inventory-Revised (TCI-R) and the presence of the 44-bp VNTR polymorphism in the 5-HTT (SLC6A4) promoter region and the 30-bp VNTR polymorphism in the MAO-A promoter region. The study also assessed the influence of personality traits on the QoL as measured by the SF-36.

\section{Materials and methods}

The study was conducted on a group of 214 healthy volunteer women from northwest Poland, being at least 1 year after the last menstruation. In order to recruit respondents, we sent the information about the study and invitation to take part in it to primary care centers in West Pomeranian province in Poland. Those interested reported to a treatment room at the appointed time. All participants provided written informed consent to take part in this study. All participants were non-smokers, drank less than $20 \mathrm{~g}$ of pure alcohol per day or drank occasionally no more than $40 \mathrm{~g}$ of pure alcohol, and abstained from alcohol at least 2 days per week. ${ }^{22}$ Endocrine, neoplastic, and mental diseases were excluded on the basis of medical history, and mental disorders by means of a screening test performed using the Primary Care Evaluation of Mental Disorders Patient Health Questionnaire 9 for diagnosing depression. The research presented here is a part of a greater project whose aim was to determine factors presumably contributing to depression in postmenopausal women. We analyzed the influence of genetic factors on personality traits (using two standardized questionnaires, namely the NEO-FFI and the TCI) and the occurrence of depression in postmenopausal women. We also measured the severity of depressive symptoms, the QoL level, and health behaviors among postmenopausal women, depending on their sociodemographic data, the severity of climacteric symptoms, and the use of MHT.

The mean age of the women was $56.8 \pm 4.08$ years; $48 \%$ of them had secondary education and $36 \%$ had higher education. The majority of the respondents (69\%) had life partners, and $53.3 \%$ were professionally active (Table 1 ).

The first stage of this study was based on a survey performed using standard research instruments: the TCI-R for analyzing personality traits and the SF-36 for measuring QoL.

The second stage of the study was based on genetic testing. A total of $10 \mathrm{~mL}$ venous blood samples were collected for genetic analysis using a closed system
Table I The structure of the study sample with regard to selected sociodemographic data

\begin{tabular}{lll}
\hline Sociodemographic data & $\mathbf{n}$ & $\%$ \\
\hline Education & & \\
Primary & 7 & 3.3 \\
Vocational & 27 & 12.6 \\
Secondary & 102 & 47.7 \\
Third level & 78 & 36.4 \\
Total & 214 & 100.0 \\
Place of residence & & \\
Village & 20 & 9.4 \\
City of $<10,000$ residents & 6 & 2.8 \\
City of I0,000-100,000 residents & 44 & 20.6 \\
City of $>100,000$ residents & 132 & 61.7 \\
No data & 12 & 5.5 \\
Total & 214 & 100.0 \\
Marital status & & \\
Single & 12 & 5.6 \\
Married & 148 & 69.2 \\
Widowed & 12 & 5.6 \\
Divorced & 42 & 19.6 \\
Total & 214 & 100.0 \\
Employment & & \\
Employed & 114 & 53.3 \\
Unemployed & 23 & 10.7 \\
Retired & 67 & 31.3 \\
Drawing a pension & 9 & 4.2 \\
No data & 1 & 0.5 \\
Total & 214 & 100.0 \\
\hline
\end{tabular}

(Vacutainer). Biological material (blood) was collected and stored after the participants gave their written consent to this procedure. The second stage of the study was based on genetic tests. DNA was isolated from whole blood by the salting-out method of Miller. Polymerase chain reaction was used to identify DNA polymorphisms. The aim of the analysis was to amplify the fragment consisting of 2-5 repetitions of the 30-bp VNTR polymorphism in the MAO-A promoter region. The following primer sequences were used: MAO-A-F, 5'-CCC-AGG-CTG-CTC-CAG-AAA-3', and MAO-A-R, 5'-GGA-CCT-GGG-CAG-TTG-TGC-3'. The sizes of the amplified fragments were 239, 209, 226, and $269 \mathrm{bp}$. In the 5HTT polymorphism analysis, the fragment including the 44-bp ins/del in the regulatory sequence (the presence or lack of 44-bp) was amplified. The following primer sequences were used: HTT-F, 5'-GGC-GTT-GCCGCT-CTG-AAT-GC-3', and HTT-R, 5'-GAG-GGA-CTGAGC-TGG-ACA-ACC-AC-3'. The sizes of the amplified fragments were 484 and $528 \mathrm{bp}$.

Statistical analysis was performed using Statistica 7.1 PL. The following tests were employed: one-way analysis of variance, Kruskal-Wallis test, multiple comparison test showing which groups differ from each other if 
Kruskal-Wallis test demonstrated significant differences between at least two of them, and Pearson linear correlation coefficient. The level of significance was set at $\alpha=0.05$. As for the polymorphisms of the investigated genes, there were no significant deviations from the Hardy-Weinberg equilibrium.

The study was approved by the Bioethical Commission of the Pomeranian Medical University in Szczecin (PUM) (permission number KB-0012/155/13).

\section{Results}

Analysis of the research material demonstrated that the distribution of genotypes of the 44-bp VNTR polymorphism in the 5-HTT (SLC6A4) promoter region was statistically significantly related to the levels of fear of uncertainty, enlightened second nature, and empathy according to the TCI $(P<0.05)$. Among carriers of the s/s genotype, the average level of fear of uncertainty (HA2) within the HA domain was 5.30 \pm 1.49 , among carriers of the $1 / \mathrm{s}$ genotype was $4.54 \pm 1.61$, and among carriers of the $1 / 1$ genotype was $4.32 \pm 1.61$. The average level of enlightened second nature (SD5) within the SD domain for the $1 / \mathrm{s}$ genotype was $8.01 \pm 1.69$, for the s/s genotype was $7.97 \pm 2.31$, and for the $1 / 1$ genotype was 7.24 \pm 2.12 . The average level of empathy (C2) within the $\mathrm{C}$ domain for the $1 / \mathrm{s}$ genotype was $5.22 \pm 1.06$, for the $\mathrm{s} / \mathrm{s}$ genotype was $4.93 \pm 1.17$, and for the $1 / 1$ genotype was $4.66 \pm 1.28$ (Table 2).

Table 2 Basic descriptive statistics concerning personality according to the TCl vs the distribution of genotypes of the 44-bp VNTR polymorphism in the 5-HTT (SLC6A4) promoter region

\begin{tabular}{|c|c|c|c|c|c|c|}
\hline \multirow[t]{3}{*}{ TCI-R } & \multirow{3}{*}{$\begin{array}{l}\bar{x} \pm S D \\
\bar{n}=2 \mid 4\end{array}$} & \multirow{2}{*}{\multicolumn{3}{|c|}{$\frac{\text { Genotype }}{\overline{\bar{x}} \pm \text { SD }}$}} & \multirow[t]{3}{*}{$\mathbf{F}$} & \multirow[t]{3}{*}{$P$-value } \\
\hline & & & & & & \\
\hline & & $1 / s(n=93)$ & $s / s(n=30)$ & $I / I(n=91)$ & & \\
\hline Novelty seeking (NS) & $18.76 \pm 3.86$ & $18.85 \pm 3.97$ & $|8.63 \pm 4.2|$ & $18.70 \pm 3.68$ & 0.050 & $>0.05$ \\
\hline Exploratory excitability (NSI) & $5.60 \pm 1.86$ & $5.52 \pm 2.09$ & $5.53 \pm 1.80$ & $5.70 \pm 1.63$ & $H(2.214)=0.498$ & $>0.05$ \\
\hline Impulsiveness (NS2) & $4.84 \pm 1.73$ & $4.75 \pm 1.65$ & $5.23 \pm 2.05$ & $4.79 \pm 1.71$ & 0.926 & $>0.05$ \\
\hline Extravagance (NS3) & $4.5 \mathrm{I} \pm \mathrm{I} .57$ & $4.73 \pm 1.44$ & $4.67 \pm 1.68$ & $4.30 \pm 1.65$ & 1.786 & $>0.05$ \\
\hline Disorderliness (NS4) & $3.81 \pm 1.43$ & $3.85 \pm 1.37$ & $3.40 \pm 1.43$ & $3.91 \pm 1.47$ & 1.518 & $>0.05$ \\
\hline Harm avoidance (HA) & $17.36 \pm 5.76$ & $17.36 \pm 6.10$ & $18.77 \pm 5.89$ & $16.90 \pm 5.34$ & 1.186 & $>0.05$ \\
\hline Anticipatory worry (HAI) & $4.82 \pm 2.26$ & $4.78 \pm 2.30$ & $5.00 \pm 2.12$ & $4.79 \pm 2.28$ & 0.113 & $>0.05$ \\
\hline Fear of uncertainty (HA2) & $4.55 \pm 1.62$ & $4.54 \pm 1.61$ & $5.30 \pm 1.49$ & $4.32 \pm 1.61$ & 4.273 & $<0.05$ \\
\hline Shyness (HA3) & $3.98 \pm 1.74$ & $4.02 \pm 1.83$ & $4.23 \pm 1.99$ & $3.85 \pm 1.56$ & 0.610 & $>0.05$ \\
\hline Fatigability (HA4) & $4.00 \pm 2.08$ & $3.99 \pm 2.15$ & $4.23 \pm 2.39$ & $3.95 \pm 1.93$ & 0.219 & $>0.05$ \\
\hline Reward dependence (RD) & $14.10 \pm 2.73$ & $14.16 \pm 2.65$ & $14.87 \pm 2.54$ & $13.78 \pm 2.84$ & 1.845 & $>0.05$ \\
\hline Sentimentality (RDI) & $6.23 \pm 1.97$ & $6.12 \pm 1.92$ & $6.57 \pm 1.76$ & $6.23 \pm 2.09$ & 0.586 & $>0.05$ \\
\hline Attachment (RD3) & $4.40 \pm 1.32$ & $4.50 \pm 1.30$ & $4.60 \pm 1.33$ & $4.23 \pm 1.33$ & 1.369 & $>0.05$ \\
\hline Dependence (RD4) & $3.48 \pm 1.33$ & $3.56 \pm 1.31$ & $3.70 \pm 1.09$ & $3.32 \pm 1.42$ & 1.238 & $>0.05$ \\
\hline Persistence $(\mathrm{P})$ & $3.82 \pm 1.35$ & $3.97 \pm 1.42$ & $3.50 \pm 1.46$ & $3.77 \pm 1.23$ & 1.471 & $>0.05$ \\
\hline Self-directedness (SD) & $27.79 \pm 5.68$ & $28.75 \pm 5.07$ & $27.93 \pm 5.84$ & $26.78 \pm 6.08$ & $H(2.2 \mid 3)=4.73$ & $>0.05$ \\
\hline Responsibility (SDI) & $5.36 \pm 1.59$ & $5.55 \pm 1.60$ & $5.20 \pm 1.58$ & $5.23 \pm 1.59$ & 1.103 & $>0.05$ \\
\hline Purposefulness (SD2) & $5.27 \pm 1.64$ & $5.34 \pm 1.63$ & $5.27 \pm 1.95$ & $5.20 \pm 1.57$ & 0.181 & $>0.05$ \\
\hline Resourcefulness (SD3) & $2.90 \pm 1.30$ & $3.16 \pm 1.01$ & $2.67 \pm 1.45$ & $2.70 \pm 1.46$ & $H(2.214)=4.19$ & $>0.05$ \\
\hline Self-acceptance (SD4) & $6.55 \pm 2.13$ & $6.59 \pm 2.03$ & $6.83 \pm 2.26$ & $6.4 I \pm 2.20$ & 0.486 & $>0.05$ \\
\hline Enlightened second nature (SD5) & $7.68 \pm 2.10$ & $8.01 \pm 1.69$ & $7.97 \pm 2.31$ & $7.24 \pm 2.12$ & 3.468 & $<0.05$ \\
\hline Cooperativeness (C) & $32.34 \pm 4.68$ & $33.17 \pm 3.96$ & $32.34 \pm 4.51$ & $31.49 \pm 5.27$ & 3.012 & $>0.05$ \\
\hline Social acceptance $(\mathrm{Cl})$ & $6.94 \pm 1.24$ & $7.17 \pm 1.15$ & $6.69 \pm 1.34$ & $6.78 \pm 1.27$ & 3.030 & $>0.05$ \\
\hline Empathy (C2) & $4.94 \pm 1.20$ & $5.22 \pm 1.06$ & $4.93 \pm 1.17$ & $4.66 \pm 1.28$ & 5.132 & $<0.05$ \\
\hline Helpfulness (C3) & $5.86 \pm 1.35$ & $5.83 \pm 1.30$ & $6.13 \pm 1.14$ & $5.79 \pm 1.46$ & 0.756 & $>0.05$ \\
\hline Compassion (C4) & $8.46 \pm 1.94$ & $8.70 \pm 1.69$ & $8.37 \pm 2.09$ & $8.25 \pm 2.11$ & 1.266 & $>0.05$ \\
\hline Pure-hearted conscience (C5) & $6.16 \pm 1.25$ & $6.26 \pm 1.21$ & $6.30 \pm 1.42$ & $6.01 \pm 1.22$ & 1.130 & $>0.05$ \\
\hline Self-transcendence (ST) & $14.63 \pm 5.62$ & $14.90 \pm 5.76$ & $13.93 \pm 4.63$ & $14.57 \pm 5.79$ & 0.344 & $>0.05$ \\
\hline Self-forgetfulness (STI) & $4.60 \pm 2.35$ & $4.75 \pm 2.31$ & $4.13 \pm 1.36$ & $4.60 \pm 2.65$ & $\mathrm{H}(2.2 \mid 4)=1.520$ & $>0.05$ \\
\hline Transpersonal identification (ST2) & $3.64 \pm 2.08$ & $3.77 \pm 2.10$ & $3.27 \pm 2.13$ & $3.64 \pm 2.05$ & 0.676 & $>0.05$ \\
\hline Spiritual acceptance (ST3) & $6.38 \pm 2.74$ & $6.38 \pm 2.85$ & $6.53 \pm 3.04$ & $6.33 \pm 2.55$ & 0.062 & $>0.05$ \\
\hline
\end{tabular}

Abbreviations: TCI, Temperament and Character Inventory; 5 -HTT, serotonin transporter; TCl-R, Temperament and Character Inventory-Revised; $\bar{x} \pm$ SD, mean \pm standard deviation; $n$, number of participants; $F, F$ (analysis of variance) test statistic; $P$, level of significance for $F$ or $\mathrm{H}$ statistic; $\mathrm{H}, \mathrm{Kruskal-W}$ allis test statistic. 
The s/s genotype was significantly more common than the 1/1 genotype among women with higher fear of uncertainty. The 1/s genotype was significantly more common than the $1 / 1$ genotype in a group of women with higher levels of enlightened second nature. The $1 / \mathrm{s}$ genotype was more common than the $1 / 1$ genotype in women with higher empathy (Table 3).

No statistically significant differences were observed between the mean scores for the TCI scales and subscales depending on the distribution of genotypes of the 30-bp VNTR polymorphism in the MAO-A promoter region $(P>0.05)$.

QoL domains according to the SF-36 and personality traits according to the TCI-R were subjected to statistical analysis. The correlation was regarded as moderate if the correlation coefficient $r=0.4-0.6$; the correlation was noticeable if $r=0.2-0.4$; and the correlation was very weak if $r<0.2$ $(P>0.05)$. Analysis of the data demonstrated moderate statistically significant relationships between enlightened second nature and QoL levels in all domains, except for bodily pain. The higher the QoL in a particular domain, the lower the expression of enlightened second nature. Analysis also demonstrated moderate statistically significant relationships between transpersonal identification and SF-36 domains such as general health, vitality, social functioning, role emotional, and mental health. An increase in QoL levels in the aforementioned domains corresponded to increased expression of the aforementioned personality trait. Additionally, moderate statistically significant relationships were observed between purposefulness and vitality, social functioning, and mental health domains - the higher the QoL level, the weaker the expressed purposefulness. Moderate statistically significant

Table 3 The results of Tukey's test for the fear of uncertainty (HA2), enlightened second nature (SD5), and empathy (C2) subscales according to the $\mathrm{TCl}-\mathrm{R}$ vs the distribution of genotypes of the 44-bp VNTR polymorphism in the 5-HTT (SLC6A4) promoter region

\begin{tabular}{|c|c|c|c|}
\hline 5-HTT & I/s & $\mathbf{s} / \mathbf{s}$ & I/I \\
\hline \multicolumn{4}{|c|}{ Fear of uncertainty (HA2) } \\
\hline $\mathrm{l} / \mathrm{s}$ & & 0.15 & 0.62 \\
\hline$s / s$ & 0.15 & & 0.04 \\
\hline $\mathrm{l} / \mathrm{I}$ & 0.62 & 0.04 & \\
\hline \multicolumn{4}{|c|}{ Enlightened second nature (SD5) } \\
\hline $1 / s$ & & 0.10 & 0.03 \\
\hline$s / s$ & 0.10 & & 0.37 \\
\hline $1 / 1$ & 0.03 & 0.37 & \\
\hline \multicolumn{4}{|c|}{ Empathy (C2) } \\
\hline $1 / s$ & & 0.62 & 0.00 \\
\hline$s / s$ & 0.62 & & 0.64 \\
\hline $1 / I$ & 0.00 & 0.64 & \\
\hline
\end{tabular}

Abbreviations: TCI-R, Temperament and Character Inventory-Revised; 5-HTT, serotonin transporter.
Table 4 Correlations between quality of life and personality traits according to the $\mathrm{TCl}-\mathrm{R}$

\begin{tabular}{|c|c|c|c|c|c|c|c|c|}
\hline \multirow[t]{2}{*}{ TCI-R } & \multicolumn{8}{|l|}{ SF-36 } \\
\hline & 赵 & 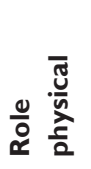 & 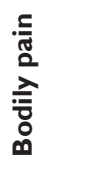 & 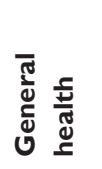 & 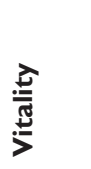 & 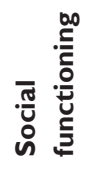 & 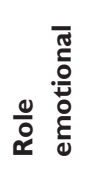 & 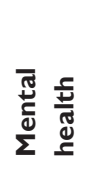 \\
\hline \multicolumn{9}{|c|}{ Novelty seeking (NS) } \\
\hline$r$ & -0.05 & -0.12 & -0.03 & -0.0 & -0.05 & -0.11 & -0.10 & -0.05 \\
\hline$P$ & $>0.05$ & $>0.05$ & $>0.05$ & $>0.05$ & $>0.05$ & $>0.05$ & $>0.05$ & $>0.05$ \\
\hline \multicolumn{9}{|c|}{ Harm avoidance (HA) } \\
\hline$r$ & 0.19 & 0.15 & 0.12 & 0.13 & 0.20 & 0.27 & 0.27 & 0.23 \\
\hline$P$ & $<0.05$ & $<0.05$ & $>0.05$ & $>0.05$ & $<0.05$ & $<0.05$ & $<0.05$ & $<0.05$ \\
\hline \multicolumn{9}{|c|}{ Reward dependence (RD) } \\
\hline$r$ & 0.12 & 0.15 & 0.10 & 0.15 & 0.28 & 0.24 & 0.25 & 0.35 \\
\hline$P$ & $>0.05$ & $<0.05$ & $>0.05$ & $<0.05$ & $<0.05$ & $<0.05$ & $<0.05$ & $<0.05$ \\
\hline \multicolumn{9}{|c|}{ Persistence (P) } \\
\hline$r$ & -0.17 & -0.10 & -0.19 & -0.13 & -0.14 & -0.17 & -0.22 & -0.26 \\
\hline$P$ & $<0.05$ & $>0.05$ & $<0.05$ & $>0.05$ & $>0.05$ & $<0.05$ & $<0.05$ & $<0.05$ \\
\hline \multicolumn{9}{|c|}{ Self-directedness (SD) } \\
\hline$r$ & 0.04 & -0.01 & 0.05 & 0.09 & 0.04 & 0.01 & 0.04 & 0.07 \\
\hline$P$ & $>0.05$ & $>0.05$ & $>0.05$ & $>0.05$ & $>0.05$ & $>0.05$ & $>0.05$ & $>0.05$ \\
\hline \multicolumn{9}{|c|}{ Cooperativeness $(C)$} \\
\hline r & 0.13 & 0.03 & 0.12 & 0.05 & 0.13 & 0.18 & 0.14 & 0.21 \\
\hline$P$ & $>0.05$ & $>0.05$ & $>0.05$ & $<0.05$ & $>0.05$ & $<0.05$ & $<0.05$ & $<0.05$ \\
\hline \multicolumn{9}{|c|}{ Self-transcendence (ST) } \\
\hline$r$ & 0.23 & 0.24 & 0.24 & 0.30 & 0.44 & 0.41 & 0.43 & 0.55 \\
\hline$P$ & $<0.05$ & $<0.05$ & $<0.05$ & $<0.05$ & $<0.05$ & $<0.05$ & $<0.05$ & $<0.05$ \\
\hline
\end{tabular}

Abbreviations: TCI-R, Temperament and Character Inventory-Revised; $r$, Pearson's linear correlation coefficient; $P$, level of significance for $r$ statistic.

relationships were also observed between ST and vitality, social functioning, role emotional, and mental health - higher QoL levels in particular domains were accompanied by increased expression of ST (Table 4).

\section{Discussion}

The studies conducted so far suggest that personality traits may be related to genetic factors. The study of 157 Hungarian students, concerning the influence of VNTR polymorphisms in the dopamine D4 receptor gene and the 5-HTT gene (SLC6A4) on personality traits according to the TCI, demonstrated that respondents with the s/s genotype of the polymorphism in the 5-HTT (SLC6A4) promoter region and the dopamine D4 receptor gene 7-repeat allele had higher levels of HA than other genotypic groups. ${ }^{23}$ Evidence was also provided for the association between the 5-HTTLPR polymorphism and neuroticism, regarded as a risk factor for affective disorders. ${ }^{24}$ According to the study carried out in Finland, neuroticism was linked to the occurrence of anxiety and depressive symptoms. ${ }^{25}$ It was also found that the presence of the "s" allele of the 5-HTTLPR polymorphism resulted 
in lower 5-HTT expression and, consequently, an increase in impulsive behaviors. As serotonergic manipulations showed, it was related to reduced serotonergic function. ${ }^{26}$ Another study focused on the influence of the 5-HTTLPR polymorphism combined with adverse effects of the home environment on developing impulsivity in adolescence. Carriers of the "s" allele of the 5-HTTLPR polymorphism displayed higher levels of impulsive behaviors than those with the "l" allele, irrespective of family relationships. ${ }^{27}$ Emotional resistance may be also affected by the low-activity MAO-A variant. Respondents with low MAO activity and the "s" allele of the 5-HTTLPR polymorphism perceived themselves as the most impulsive of all respondents. ${ }^{28}$ Furthermore, it was demonstrated that maltreated children with the low-activity MAO-A genotype had significantly more frequent behavior disorders and antisocial personality than children with the high-activity MAO-A genotype. ${ }^{29}$ The study of 371 male alcohol addicts and 236 male controls suggests that impulsive and antisocial personality traits are to some degree associated with the genotype of $M A O-A$, including the 3 - or 5-repeat versions. ${ }^{30}$

Our study shows that the distribution of genotypes of the 44-bp VNTR polymorphism in the 5-HTT (SLC6A4) promoter region contributes to higher scores for fear of uncertainty, enlightened second nature, and empathy. At the same time, the distribution of genotypes of the 30-bp VNTR polymorphism in the MAO-A promoter region had no influence on personality traits. The results of our previous research conducted using the NEO-FFI, which is another standardized questionnaire for measuring personality traits, demonstrated that women with the $3 / 3$ genotype of the 30-bp VNTR polymorphism in the MAO-A promoter region were characterized by a lower level of openness to experience than women with other MAO-A genotypes. ${ }^{31}$

An interesting study of 1102 subjects was conducted in Israel. It concerned the influence of personality traits on the perception of happiness and well-being. Research instruments employed in this study were the TCI, the Positive and Negative Affect Schedule, the Satisfaction with Life Scale, the Multidimensional Scale of Perceived Social Support, and the General Health Questionnaire. Cloninger and Zohar demonstrated that SD was strongly related to the perception of all aspects of happiness and well-being. C correlated mainly with the perception of social support. ST was associated with feeling positive emotions. Emotional, social, and physical aspects of happiness and well-being were interrelated, but they were also influenced by specific configurations of personality dimensions. ${ }^{32}$ Similar results were obtained in our research, demonstrating the connection between particular aspects of QoL and two subscales of $\mathrm{SD}$, namely purposefulness (SD2) and enlightened second nature (SD5) - the higher the QoL, the lower the levels of these traits. A decline was also noticed in the transpersonal identification (ST2) subscale as the QoL increased in selected domains. Bonacchi et al analyzed the impact of temperament and character traits on the QoL of patients with a diagnosis of neoplastic disease. Research instruments employed in this study were the TCI, the SF-36, and the Hospital Anxiety and Depression Scale. The study involved a group of 203 oncological patients. Low scores for HA and high scores for SD significantly correlated with health-related quality of life (HRQoL). The results indicated to some relationship between HRQoL and traits of temperament and character. ${ }^{33}$ Research shows that personality may be a sort of buffer for patients with mental disorders who experienced traumatic events. Irrespective of their traumatic experiences in the past, patients with low levels of neuroticism and high levels of extroversion, agreeableness, conscientiousness, and openness to experience assessed their QoL and social functioning better than their counterparts with other personality profiles. ${ }^{34}$ The literature also describes studies concerning the contribution of personality dimensions to major behavioral obsessions such as gambling, compulsive shopping, sex, work, addiction to computer and the Internet, or physical exercises. One of available studies involved a group of 158 outpatients with bipolar affective disorder and a group of 200 healthy controls. Its results showed that patients with bipolar affective disorder and at least one of behavioral addictions obtained lower scores for SD $(P=0.007)$ and $\mathrm{C}(P=0.014)$ than those without behavioral addictions. ${ }^{35}$

In our study, increased expression of some personality traits, such as enlightened second nature, ST, and transpersonal identification, had effects on the QoL level. The published results of our previous research, based on the NEO-FFI questionnaire, demonstrated the impact of extroversion and neuroticism on all QoL domains, the influence of agreeableness on all QoL domains apart from bodily pain, and the effects of conscientiousness on all QoL domains except for physical fitness, pain, and general health. Higher neuroticism was proved to be associated with a lower QoL level, and extroversion was proved to be associated with a higher QoL level. Identification of the homogeneous groups of women at a higher risk of a decline in the QoL and development of depressive symptoms may result in the preventive care for postmenopausal women, aiming at the improvement of their functioning and reduction of adverse effects of depression. 


\section{Limitations}

We analyzed the influence of genetic factors on expression of personality traits and measured QoL with regard to personality factors. Our study included 214 postmenopausal women. The larger size of the study sample would undoubtedly increase the scientific value of the study. Nevertheless, the research on personality traits with regard to genetic factors gives a new look at biological determinants of the QoL of postmenopausal women. The limitations of the present study do not allow us to extend our conclusions to the general population. Still, we believe that it has the potential to provide interesting findings in the field requiring further research.

\section{Conclusion}

This study confirmed that the s/s genotype of the 44-bp VNTR polymorphism in the 5-HTT (SLC6A4) promoter region may contribute to a higher tendency to avoid harm within the fear of uncertainty dimension. Carriers of this genotype may have increased predisposition to anxiety and depressive disorders.

The 1/s genotype of the 44-bp VNTR polymorphism in the 5-HTT (SLC6A4) promoter region contributes to increased expression of personality traits, such as enlightened second nature and empathy.

Some personality traits may influence the quality of women's lives.

\section{Disclosure}

The authors report no conflicts of interests in this work.

\section{References}

1. Canli T, Lesch KP. Long story short: the serotonin transporter in emotion regulation and social cognition. Nat Neurosci. 2007;10(9): 1103-1109.

2. Samochowiec J, Fiszer-Piosik E, Kucharska-Mazur J, Horodnicki J. Wpływ genów na kształtowanie się cech osobowości [The influence of genes on the development of personality]. Psychiatr Pol. 2000;34(1): 99-109. Polish [with English abstract].

3. Zakrzewska M, Samochowiec J, Rybakowski F, Hauser J, PełkaWysiecka J. Polska wersja Inwentarza Temperamentu i Charakteru (TCI): analiza rzetelności [Polish version of Temperament and Character Inventory (TCI): the analysis of reliability]. Psychiatr Pol. 2001;35(3):455-465. Polish [with English abstract].

4. Jakubczyk A, Wojnar M: Genetyczne i psychospołeczne uwarunkowania impulsywności. Post PsychiatrNeurol. 2010;19(1):39-45.

5. Caspi A, Sugden K, Moffitt TE, et al. Influence of life stress on depression: moderation by a polymorphism in the 5-HTT gene. Science. 2003; 301(5631):386-389.

6. Gardini S, Cloninger CR, Venneri A. Individual differences in personality traits reflect structural variance in specific brain regions. Brain Res Bull. 2009;79(5):265-270.

7. Cheung G. Stability of the harm avoidance personality trait in late-life depression. Int Psychogeriatr. 2007;19(4):778-780.

8. Hauser J, Dmitrzak-Węglarz M. Leksykon genetyki w psychiatrii. Poznań: Termedia Wydawnictwa Medyczne; 2010.
9. Prazeres F, Santiago L. Relationship between health-related quality of life, perceived family support and unmet health needs in adult patients with multimorbidity attending primary care in Portugal: a multicentre cross-sectional study. Health Qual Life Outcomes. 2016;14(1):156.

10. Steptoe A, Deaton A, Stone AA. Psychological wellbeing, health and ageing. Lancet. 2015;385(9968):640-648.

11. Pertyński T, Stetkiewicz T. Perimenopauza. In: Pertyński T, editor. Diagnostyka i terapia wieku menopauzalnego [Diagnosis and therapy at the menopausal age]. Wrocław: Wyd. Med. Urban \& Partner; 2004:313-322

12. Jakimiuk AJ, Postawski K. Atrofia pochwy. In: Pertyński T, editor. Diagnostyka i terapia wieku menopauzalnego. Wrocław: Wyd. Med. Urban \& Partner; 2004:189-198.

13. Rechberger T. Nietrzymanie moczu u kobiet- problem medyczny, społeczny i socjalny. In: Pertyński T, editor. Diagnostyka i terapia wieku menopauzalnego. Wrocław: Wyd. Med. Urban \& Partner; 2004: 41-63.

14. Kornacewicz-Jach Z. Choroby serca i naczyń w wieku menopauzalnym. In: Pertyński T, editor. Diagnostyka i terapia wieku menopauzalnego. Wrocław: Wyd. Med. Urban \& Partner; 2004:23-39.

15. Pawelczyk L, Sokalska A. Osteopenia i osteoporoza wieku menopauzalnego. In: Pertyński T, editor. Diagnostyka i terapia wieku menopauzalnego. Wrocław: Wyd. Med. Urban \& Partner; 2004:238-249.

16. Cohen LS, Soares CN, Vitonis AF, Otto MW, Harlow BL. Risk for new onset of depression during the menopausal transition: the Harvard study of moods and cycles. Arch Gen Psychiatry. 2006;63(4):385-390.

17. Skałba P. Przekwitanie, klimakterium. In: Skałba P, editor. Endokrynologia ginekologiczna. Warszawa: Wydawnictwo Lekarskie PZWL; 2008 304-305.

18. Speroff L, Glass RH, Kase NG. Clinical Gynecologic Endocrinology and Infertility. 6th ed. Baltimore: Lippincott Williams and Wilkins; 1999.

19. Pertyński T. Diagnostyka i terapia wieku menopauzalnego [Diagnosis and therapy at the menopausal age]. Wrocław: Wyd. Med. Urban \& Partner; 2004

20. Ratajczak Z. Jakość życia czlowieka $w$ warunkach narastających zagrożeń. Warszawa: Wyd. Uniw. Warszawskiego; 2005.

21. Dąbrowska J, Naworska B, Dąbrowska-Galas M. Rola wysiłku fizycznego w okresie menopauzy. Prz Menopauz. 2012;6:445-448.

22. State Agency for Solving Alcohol Problems [homepage on the Internet]. Available from: http://www.parpa.pl/index.php. Accessed November 15, 2016

23. Szekely A, Ronai Z, Nemoda Z, Kolmann G, Gervai J, Sasvari-Szekely M. Human personality dimensions of persistence and harm avoidance associated with DRD4 and 5-HTTLPR polymorphisms. Am J Med Genet B Neuropsychiatr Genet. 2004;126B(1):106-110.

24. Stein MB, Campbell-Sills L, Gelernter J. Genetic variation in 5HTTLPR is associated with emotional resilience. Am J Med Genet B Neuropsychiatr Genet. 2009;150B(7):900-906.

25. Jylhä $\mathrm{P}$, Isometsä $\mathrm{E}$. The relationship of neuroticism and extraversion to symptoms of anxiety and depression in the general population. Depress Anxiety. 2006;23(5):281-289.

26. Walderhaug E, Lunde H, Nordvik JE, Landrø NI, Refsum H, Magnusson A. Lowering of serotonin by rapid tryptophan depletion increases impulsiveness in normal individuals. Psychopharmacology (Berl). 2002;164(4):385-391.

27. Paaver M, Kurrikoff T, Nordquist N, Oreland L, Harro J. The effect of 5-HTT gene promoter polymorphism on impulsivity depends on family relations in girls. Prog Neuropsychopharmacol Biol Psychiatry. 2008;32(5):1263-1268.

28. Paaver M, Nordquist N, Parik J, Harro M, Oreland L, Harro J. Platelet MAO-activity and the 5-HTT gene promoter polymorphism are associated with impulsivity and cognitive style in visual information processing. Psychopharmacology (Berl). 2007;194(4):545-554.

29. Caspi A, McClay J, Moffitt TE, et al. Role of genotype in the cycle of violence in maltreated children. Science. 2002;297(5582):851-854. 
30. Laqua C, Zill P, Koller G, Preuss U, Soyka M. [Association between the MAOA-uVNTR polymorphism and antisocial personality traits in alcoholic men]. Fortschr Neurol Psychiatr. 2015;83(3):162-169. German [with English abstract].

31. Schneider-Matyka D, Jurczak A, Samochowiec A. Analysis of personality traits and their influence on the quality of life of postmenopausal women with regard to genetic factors. Ann Gen Psychiatry. 2016; 15(1):25.

32. Cloninger CR, Zohar AH. Personality and the perception of health and happiness. J Affect Disord. 2011;128(1-2):24-32.
33. Bonacchi A, Miccinesi G, Guazzini M, et al. Temperament and character traits associated with health-related quality of life in cancer patients. Tumori. 2012;98(3):377-384.

34. Boyette LL, van Dam D, Meijer C, et al. Personality compensates for impaired quality of life and social functioning in patients with psychotic disorders who experienced traumatic events. Schizophr Bull. 2014; 40(6):1356-1365.

35. Di Nicola M, Tedeschi D, Mazza M, et al. Behavioral addictions in bipolar disorder patients: role of impulsivity and personality dimensions. J Affect Disord. 2010;125(1-3):82-88.
Clinical Interventions in Aging

\section{Publish your work in this journal}

Clinical Interventions in Aging is an international, peer-reviewed journal focusing on evidence-based reports on the value or lack thereof of treatments intended to prevent or delay the onset of maladaptive correlates of aging in human beings. This journal is indexed on PubMed Central, MedLine,

\section{Dovepress}

CAS, Scopus and the Elsevier Bibliographic databases. The manuscript management system is completely online and includes a very quick and fair peer-review system, which is all easy to use. Visit http://www.dovepress. com/testimonials.php to read real quotes from published authors. 